\title{
Isolation of Aeromonas species from clinical sources
}

\author{
A. W. McCRACKEN AND R. BARKLEY
}

From the Division of Microbial Pathology, Department of Pathology, The University of Texas Medical School, San Antonio, Texas

SYNOPSIS In a period of one year, in a general hospital, Aeromonas hydrophila was isolated from 13 patients and Aeromonas shigelloides from one patient. Eight of the patients had superficial infections. two had urinary tract infections, and four had bacteriaemia. The association of Aeromonas bacteriaemia with cirrhosis of the liver and malignant disease, which has been previously reported, was observed in three of the four bacteriaemic patients. The key to laboratory diagnosis of this genus is the routine performance of the oxidase test in bacteriological procedures for the identification of Gram-negative bacilli.

Organisms belonging to the genus Aeromonas are seldom associated with human infections. Nevertheless, there are indications from sources in the United States and Australia that, in common with

${ }^{1}$ Present address: Department of Pathology, University of Texas Medical School at Houston, Texas Medical Center, Houston, Texas.

Received for publication 21 August 1972. other exotic Gram-negative bacteria, Aeromonas is being isolated with increasing frequency from clinical sources (von Graevenitz and Mensch, 1968; Cooper and Brown, 1968). During the period January 1971 to January 1972 Aeromonas hydrophila was isolated from 13 patients in Bexar County Hospital, Sarb Antonio, Texas. Four of these patients had Aero ?

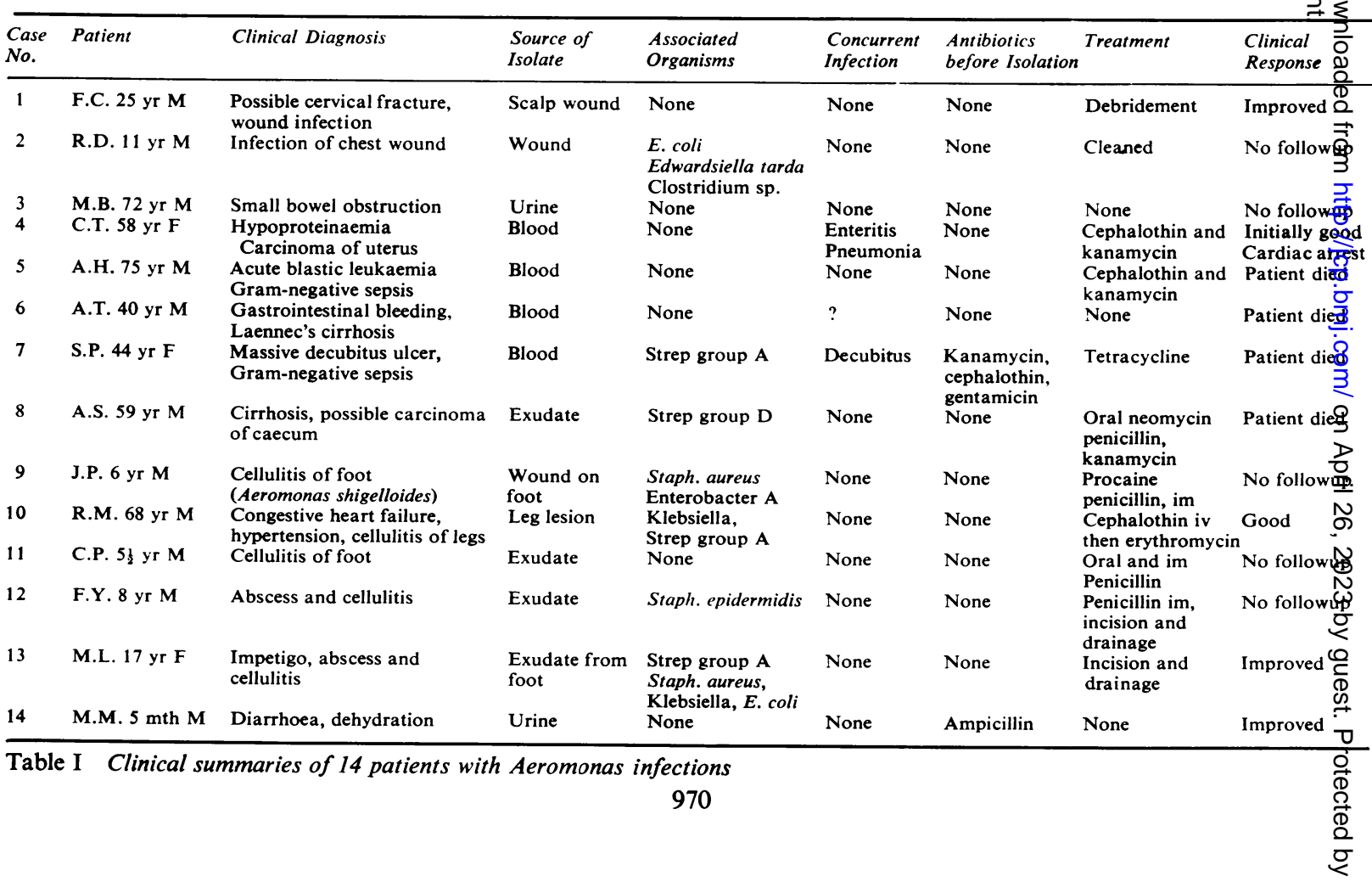


monas bacteriaemia. Aeromonas shigelloides was isolated from one other patient during that period.

\section{Case Reports}

Clinical and bacteriological summaries of these 14 patients are shown in Table I. To illustrate the clinical course of some of these infections seven of the patients are presented here in more detail. Permission for necropsy was not obtained in the four fatal cases.

PATIENT NO. 1

F.C., a healthy 25-year-old man, dived into a swimming pool and struck his head on the bottom. He was admitted to hospital with a 4-in. laceration of the scalp and a suspected fracture of the cervical vertebrae. On the day after his admission the wound was purulent and a pure growth of Aeromonas hydrophila was obtained from the pus. At this time the patient's white cell count was $19000 \mathrm{cmm}$ with polymorphs predominating. The wound was extensively cleaned and the patient discharged the next day. He was not given antibiotics and his recovery was uneventful.

PATIENT NO. 2

R.D., an 11-year-old boy, received a superficial puncture of the chest from the branch of a dead tree while swimming in a lake. The following day the patient was admitted to hospital at which time the wound was inflamed and tender; his temperature was $99 \cdot 8^{\circ} \mathrm{F}$, and his white cell count was 20000 per $\mathrm{cmm}$. A heavy growth of Aeromonas hydrophila in mixed culture with moderate numbers of Escherichia coli and a few colonies of Clostridium welchii and Edwardsiella tarda was isolated from the wound. Surgical debridement was carried out and the patient made a good recovery without antibiotics.

PATIENT NO. 3

M.B., a 72-year-old man, was admitted to hospital with a diagnosis of intestinal obstruction secondary to chronic duodenal ulceration. The patient also had benign prostatic hypertrophy and was catheterized once. A urine culture at this time was sterile but over the next few days Aeromonas hydrophila in excess of $10^{5}$ organisms per $\mathrm{ml}$ of urine, together with insignifisant numbers of Escherichia coli, were isolated from further samples of urine. The patient did not develop any signs and symptoms of urinary tract infection. Further catheterization was not required and within eight days the bacteriuria cleared completely without antibiotic therapy. The patient was released after a good response to conservative treatment of his intestinal complaint.
PATIENT NO. 4

C.T., a 58-year-old woman, came to hospital with a complaint of generalized oedema and severe diarrhoea of six months' duration. She had no previous history of cardiac, urinary, or liver disease. Shortly after admission a Foley catheter was inserted. After diuresis was induced the patient was found to be markedly hypoproteinaemic (serum proteins = $3.5 \mathrm{~g}$ per $100 \mathrm{ml}$ ) and 3 units of albumin were infused. Preliminary investigations suggested that the patient had a carcinoma of the uterus with spread to the colon and a secondary protein-losing enteropathy. Two blood cultures taken on admission were sterile but after two days in hospital she became febrile and rapidly comatose. A white cell count at this time was 23000 per $\mathrm{cmm}$, with $86 \%$ polymorphs, and a platelet count was 90000 per $\mathrm{cmm}$. A diagnosis of Gram-negative sepsis was made and two blood cultures taken on the third day after admission were positive for Aeromonas hydrophila. She was treated with cephalothin and kanamycin and showed some clinical improvement. On the second day in hospital she developed lower intestinal bleeding, followng which 2 units of blood were given. When the antibiotic sensitivity pattern of the organism was known the patient was treated with gentamicin but she continued to have periods of extreme hypotension and died five days after admission.

PATIENT N.O. 5

A.H. was a 75-year-old man known to have blast cell leukaemia and bronchiectasis. He was admitted to hospital with a diagnosis of Gram-negative bacteriaemia. On admission he was febrile and disorientated and numerous petechiae were present on the skin. He was treated with cephalothin and kanamycin. Shortly after admission he became markedly hypotensive but improved initially with parenteral hydrocortisone. The following day, however, he began to have respiratory distress and died shortly after from cardio-respiratory arrest. Three blood cultures were taken before antibiotic therapy; all three were positive for Aeromonas hydrophila.

PATIENT NO. 6

A.T., a 40-year-old bartender, was admitted to hospital with upper gastrointestinal bleeding and melaena. He had a history of alcoholic liver disease and a previous episode of gastrointestinal haemorrhage. On admission the patient had retention of urine and a catheter was inserted. The source of gastrointestinal bleeding was found to be a large gastric ulcer. After transfusion of 4 units of blood the patient was treated conservatively and the gastric bleeding stopped the day after admission. The next day, however, he was febrile and had deep vein 
thrombophlebitis in both legs. A white cell count at this time was 30000 per $\mathrm{cmm}$. Later the same day, following a marked decrease in urinary output, he became very restless and disorientated and he died suddenly. Antibiotic treatment was not given. Two blood cultures taken on the day he died were positive for Aeromonas hydrophila.

\section{PATIENT NO. 7}

S.P., a 44-year-old quadriplegic woman, was admitted to hospital with large decubitus ulcers of the back and extremities and a history of fever and chills in the previous three weeks. The patient had had an indwelling catheter since a fracture of the cervical vertebrae occurred in a car accident four years previously rendering her quadriplegic. On admission she was febrile with a blood pressure of $60 / 40 \mathrm{~mm} \mathrm{Hg}$. Her white cell count was 26000 per cmm with $93 \%$ polymorphs. Serum protein was $4.5 \mathrm{~g}$ per $100 \mathrm{ml}$. A diagnosis of Gram-negative endotoxin shock was made, blood cultures were obtained, and treatment with gentamicin was begun. Initial blood cultures were positive for group A beta-haemolytic streptococci and Bacteroides oralis; bluod cultures taken after antibiotic therapy was begun were positive for Aeromonas hydrophila. On the second day tetracycline was substituted for gentamicin but despite this and supportive measures the patient continued to have episodes of hypotension and died four days after admission.

\section{Bacteriology}

Swabs of pus or exudates were plated out aerobically and anaerobically on $7.5 \%$ sheep blood agar plates and on McConkey's medium and were inoculated into thioglycollate tubes. Quantitative urine cultures were plated with a calibrated loop on blood agar and McConkey's medium. Blood cultures were performed by inoculation of a $100 \mathrm{ml}$ bottle of Thiol ${ }^{1}$ broth, a thioglycollate tube, and a tube containing $3.8 \%$ 'Difco, Detroit, Michigan.

\begin{tabular}{|c|c|c|}
\hline & Aeromonas hydrophila & Aeromonas shigelloides \\
\hline $\mathbf{O} / \mathbf{F}$ & $\mathbf{F}$ & $\mathbf{F}$ \\
\hline \multicolumn{3}{|l|}{ Gas from other } \\
\hline carbohydrates & $+(-)$ & - \\
\hline Glucose & acid & acid \\
\hline $\begin{array}{l}\text { Lactose } \\
\text { Maltose }\end{array}$ & $\begin{array}{l}\text { - (acid) } \\
\text { - (acid) }\end{array}$ & $\begin{array}{l}\operatorname{acid}(-) \\
\operatorname{acid}(-)\end{array}$ \\
\hline Sucrose & $\operatorname{acid}(-)$ & - \\
\hline Xylose & - & - \\
\hline Mannitol & acid & - \\
\hline Aesculin & $+(-)$ & - \\
\hline Catalase & $+(-)$ & $+(-)$ \\
\hline Oxidase & + & $\perp$ \\
\hline Urea & $-(+)$ & - \\
\hline Nitrate & + & + \\
\hline Indole & $+(-)$ & - \\
\hline Methyl red & $+(-)$ & + \\
\hline Voges-Prauskauer & - or + & - \\
\hline \multirow{2}{*}{$\begin{array}{l}\text { TSI slant } \\
\text { butt }\end{array}$} & Alk(acid) & Alk(acid \\
\hline & - & - \\
\hline Gelatin & $+(-)$ & - \\
\hline Pigment & - & - \\
\hline \multirow{3}{*}{$\begin{array}{r}\text { Growth at } 35^{\circ} \mathrm{C} \\
37^{\circ} \mathrm{C} \\
42^{\circ} \mathrm{C}\end{array}$} & + & + \\
\hline & + & + \\
\hline & $+(-)$ & $+(-)$ \\
\hline \multirow{6}{*}{$\begin{array}{l}\text { Motility } \\
\text { KCN } \\
\text { Lysine decarboxylase } \\
\text { Arginine dihydrolase } \\
\text { Ornithine } \\
\text { decarboxylase } \\
\text { Citrate }\end{array}$} & & + \\
\hline & $+(-)$ & $-(+)$ \\
\hline & $-(+)$ & \\
\hline & + & $+(-$ \\
\hline & - & - or - \\
\hline & $+(-)$ & - \\
\hline \multicolumn{3}{|c|}{ Growth on McConkey's } \\
\hline medium & + & + \\
\hline \multicolumn{3}{|c|}{$\begin{array}{l}\text { Table II Biochemical and physical properties of } \\
\text { Aeromonas hydrophila and Aeromonas shigelloides }\end{array}$} \\
\hline \multicolumn{3}{|c|}{$\begin{array}{l}()=\text { minority reaction } \\
+ \text { or }-=\text { approximately } 50 \% \text { of isolates positive, } 50 \% \text { negative }\end{array}$} \\
\hline
\end{tabular}

sodium citrate. From this latter tube a pour-plate was prepared with $0.5 \%$ trypticase soy agar. Aero- $\overrightarrow{\overrightarrow{0}}$ monas hydrophila was isolated from aerobic and3 anaerobic cultures. The colonies resembled many? other Gram-negative rods in colonial morphology? but were recognized as possible Aeromonas species by the application of the oxidase test to colonies of all Gram-negative rods as a routine screening procedure on initial isolation. Twelve of the 13i isolates showed beta haemolytic colonies on blood

\begin{tabular}{|c|c|c|c|c|}
\hline \multirow[t]{2}{*}{ Antibiotic } & \multicolumn{2}{|l|}{ Present Series } & \multicolumn{2}{|c|}{ Results Summarized from Literature } \\
\hline & No. of Isolates Tested & No. Resistant & No. Isolates Tested & No. Resistant \\
\hline $\begin{array}{l}\text { Penicillin } \\
\text { Ampicillin } \\
\text { Carbenicillin } \\
\text { Streptomycin } \\
\text { Cephalothin } \\
\text { Gentamicin } \\
\text { Tetracycline } \\
\text { Polymyxin E } \\
\text { Kanamycin } \\
\text { Chloramphenicol }\end{array}$ & $\begin{array}{r}10 \\
10 \\
3 \\
10 \\
10 \\
3 \\
10 \\
10 \\
10 \\
10\end{array}$ & $\begin{array}{l}10(100 \%) \\
10(100 \%) \\
3(100 \%) \\
6(66.6 \%) \\
4(40 \%) \\
1(33.3 \%) \\
0 \\
0 \\
0 \\
0\end{array}$ & $\begin{array}{r}25 \\
63 \\
70 \\
52 \\
3 \\
71 \\
56 \\
48 \\
71\end{array}$ & $\begin{array}{l}25(100 \%) \\
62(98 \%) \\
- \\
8(11 \%) \\
38(73 \%) \\
0 \\
1(1.4 \%) \\
24 \%) \\
1(2 \%) \\
0\end{array}$ \\
\hline
\end{tabular}

Table III Antibiotic resistance of Aeromonas in the present series and summarized from the literature 
agar. The biochemical reactions used for the identification of Aeromonas hydrophila and Aeromonas shigelloides are shown in Table II. Antibiotic sensitivity tests were carried out by the method of Bauer, Kirby, Sherris, and Turck (1966) on 10 of the 14 isolates. The results are shown in Table III where they are compared with the reported sensitivities of Aeromonas isolated from human sources.

\section{Discussion}

Priority in the earliest description of a member of the genus Aeromonas should probably be given to Sanarelli (1891) who described a bacterium which he named Bacillus hydrophilus fuscus (Ewing, Hugh, and Johnson, 1961). This organism is probably that which is now known as Aeromonas hydrophila. Organisms of this genus are Gram-negative, facultative anaerobes, motile with polar flagella. They are usually beta-haemolytic on blood agar and ferment carbohydrates with the production of acid and gas (Table II).

The nomenclature and classification of the genus are discussed in detail by Eddy (1960), Ewing et al (1961), Meeks (1963), Schubert (1967), and Gillardi (1967). Identification and classification of the Aeromonas group of organisms in our laboratory are based on the work of Ewing et al (1961), who recognized three species-Aeromonas hydrophila, Aeromonas salmonicida, and Aeromonas shigelloides. With one exception all the isolates described here belong to the species Aeromonas hydrophila; one strain was identified as Aeromonas shigelloides. The name Plesiomonas shigelloides has also been proposed for this species (Habs and Schubert, 1962).

This genus has long been known to be a pathogen for fish, reptiles, and amphibians (Wilson and Miles, 1964; Heywood, 1968). Isolates from human sources have been shown to cause sepsis and death in mice,

\begin{tabular}{lc}
\hline Source & No. of Isolates \\
\hline Stool & 66 \\
Postoperative wounds, abscesses, superficial cellulitis & 28 \\
Blood & 23 \\
Urine & 8 \\
Sputum and/or throat & 9 \\
Nasopharynx & 5 \\
Bile & 6 \\
Intraabdominal abscesses, peritoneum, dialysis fluid & 5 \\
Total & 150 \\
\hline
\end{tabular}

Table IV Sources of 150 reported isolates of Aeromonas

rabbits, and guinea pigs (Kjems, 1955; Miles and Halnan, 1937; Pittman, 1953).

In the majority of the 150 isolates from human sources described in the literature (Table IV) no clinical information was given. Twenty-five cases of Aeromonas bacteriaemia have been reported, 12 of which have included clinical data. These together with the four patients (Nos. 4, 5, 6, and 7) with bacteriaemia described here are summarized in Table V). Among these 16 patients, five had hepatic cirrhosis and six had some form of acute leukaemia or lymphoma. Impairment of host defence mechanisms such as defective filtration by the cirrhotic liver (Conn, 1964) and the immunosuppressive effects of antileukaemic therapy (von Graevenitz and Mensch, 1968) has been suggested as playing a part in the pathogenesis of these bacteriaemias. The four patients with Aeromonas bacteriaemia described here died. From three of these patients Aeromonas hydrophila was obtained in pure culture from the blood; from one it was one of the organisms isolated from a polymicrobic bacteriaemia. Three of the bacteriaemic patients had marked hypoproteinaemia which may have been a further predisposing factor. The source of infection in these four patients could not be elucidated. Although all four had urinary catheters inserted, and it is tempting to consider this

\begin{tabular}{|c|c|c|c|c|}
\hline Case No. & Authors & Year & Clinical Diagnosis & No. Positive Blood Cultures \\
\hline 1 & Kjems & 1955 & Hepatic cirrhosis & 3 \\
\hline 2 & & & Rheumatic fever & 1 \\
\hline 3 & Conn & 1964 & Cirrhosis and peritonitis & 1 \\
\hline 4 & & & Cirrhosis and peritonitis & 1 \\
\hline 5 & Bulger and Sherris & 1966 & Lymphoblastic leukaemia & 3 \\
\hline 6 & Dean and Post & 1967 & Acute myelogenous leukaemia & 5 \\
\hline 7 & von Graevenitz and Mensch & 1968 & Cirrhosis and pneumonia & 2 \\
\hline 8 & & & Chronic cholecystitis & $\overline{1}$ \\
\hline 9 & Lopez et al & 1968 & Acute myelogenous leukaemia & 4 \\
\hline 10 & Slotnick & 1970 & Leukaemia & 2 \\
\hline 11 & & & Reticulum cell sarcoma & 3 \\
\hline 12 & & & Bleeding ulcer & 1 \\
\hline 13 & Present series & 1972 & Cirrhosis and gastrointestinal haemorrhage & 1 \\
\hline 14 & & & Cancer of uterus & 2 \\
\hline 15 & & & Quadriplegia: decubitus ulcers & 1 \\
\hline 16 & & & Acute leukaemia & 3 \\
\hline
\end{tabular}

Table V Clinical diagnosis in 16 patients with Aeromonas bacteriaemia 
a likely source of the bacteriaemia, none of them had clinical or bacteriological evidence of urinary tract infection by Aeromonas. The clinical picture of these four patients was indistinguishable from that due to other Gram-negative bacteria. Patients 4 and 5 developed the signs and symptoms of bacterial endotoxin shock with episodes of profound hypotension. Aeromonas infection of the urinary tract occurred in two patients (patients 3 and 14) from whom the organism was isolated in pure culture and in significant numbers. These two infections were thought to be acquired in hospital; patient no. 3 was catheterized and this was a probable source of infection. In patient no. 14 the source was not apparent although the use of ampicillin may have favoured the selection of Aeromonas as the infecting organism. Numerous hospital environmental samples over the past three years have not yielded a single isolation of Aeromonas among the many other Gram-negative species isolated.

Localized skin and soft tissue infections occurred mainly on the lower limbs; sometimes there was a preceding history of minor trauma. The single isolate of Aeromonas shigelloides was obtained from a patient who stepped on a rusty nail. The infections of the scalp and chest wall (patients 1 and 2) both occurred following swimming mishaps. The association of Aeromonas infections with exposure to contaminated water has been reported for pulmonary infections following drowning and for wound sepsis (von Graevenitz and Mensch, 1968).

There have been a number of reports of the association of Aeromonas species with gastrointestinal disease (Gillardi, 1967; Mohiedin, Gabr, El-Hefny, Mahmoud, and Abdallah, 1965; Lautrop, 1961) which has usually taken the form of mild to severe gastroenteritis. The significance of these associations is difficult to assess since up to $3.2 \%$ of normal people have been found to excrete Aeromonas in the faeces (Rosner, 1964; Paučková and Fukalová, 1968; von Graevenitz and Zinterhofer, 1970). The presence of the organism as a normal inhabitant of the gut would account for the isolation of Aeromonas from patients with peritonitis, postoperative wound infections and abscesses (Bras, Clearkin, Annamunthodo, and Caselitz, 1954; Bottone and Allerhand, 1970; Sonnenwirth, 1970). Cooper and Brown (1968) reported the association of Plesiomonas (Aeromonas) shigelloides with enteritis in children in Australia.

The results of antibiotic sensitivity tests (Table III) did not differ significantly from those previously reported by many authors. The resistance of Aeromonas to penicillin and ampicillin is probably due to the production of beta-lactamase (Bulger and Sherris, 1966). Aeromonas species are consistently sensitive to chloramphenicol and tetracycline and Abrams, Zierdt, and Brown (1971) have suggested that these antibiotics be given in combination as soon as a tentative diagnosis of Aeromonas infection is made. However, in patients with Aeromonas septicaemia the use of an appropriate bactericidal antibiotic such as kanamycin should also be considered.

The occurrence of 14 instances of Aeromonas infections in one general hospital in one year is possibly fortuitous although in the previous two years only three or four isolates of this organism were obtained in our laboratory. However, Aeromonas species can readily be overlooked if the oxidase test is not performed on colonies of Gram-negative rods. We believe that many laboratories may fail to recognize the Aeromonas group for this reason and recommend the use of the oxidase test as a routine procedure in this area of diagnostic bacteriology.

We are grateful to Dr C. U. Mauney and Dr T. W. Huber for their invaluable assistance.

\section{References}

Abrams, E., Zierdt, C. H., and Brown, J. A. (1971). Observations on Aeromonas hydrophila septicaemia in a patient with leukaemia. J. clin. Path., 24, 491-492.

Bauer, A. W., Kirby, W. M. B., Sherris, J. C., and Turck, M. (1966). Antibiotic susceptibility testing by a standardized single disk method. Amer. J. clin. Path., 45, 493-496.

Bottone, E., and Allerhand, J. (1970). Aeromonas and Serratio comparative study of extracellular deoxyribonuclease pr duction and other biochemical characteristics. Amer. J. cling Path., 53, 378-382.

Bras, G., Clearkin, K. P., Annamunthodo, H., and Caselitz, F. H. (1954). Abdominal actinomycosis associated with idiopathic gangrene of scrotum. West Ind. med. J., 3, 137-140.

Bulger, R. J., and Sherris, J. C. (1966). The clinical significance of Aeromonas hydrophila: report of two cases. Arch. intern. Med., $118,562-564$.

Conn, H. O. (1964). Spontaneous peritonitis and bacteremia in Laennec's cirrhosis caused by enteric organisms. Ann. intern. Med., 60, 568-580.

Cooper, R. G., and Brown, G. W. (1968). Plesiomonas shigelloides in South Australia. J. clin. Path., 21, 715-718.

Dean, H. M., and Post, R. M. (1967). Fatal infection with Aeromonas hydrophila in a patient with acute myelogenous leukemia. $A n n$. intern. Med., 66, 1177-1179.

Eddy, B. P. (1960). Cephalotrichous, fermentative gram-negative bacteria: the genus Aeromonas. J. appl. Bact., 23, 216-249.

Ewing, W. H., Hugh, R., and Johnson, J. G. (1961). Studies on the Aeromonas Group. Communicable Diseases Center, Atlanta. Georgia.

Gillardi, G. L. (1967). Morphological and biochemical characteristics of Aeromonas punctata (hydrophila, liquefaciens) isolated from human sources. Appl. Microbiol., 15, 417-421.

Habs, H., and Schubert, R. H. W. (1962). Uber die biochemischen Merkmale und die taxonomische Stellung von Pseudomonas $\mathrm{N}$ shigelloides (Bader). Zbl. Bakt., I. Abt. Orig., 186, 316-327.

Heywood, R. (1968). Aeromonas infection in snakes. Cornell Vet., 58, N 236-241.

Kjems, E. (1955). Studies on five bacterial cultures of the genus $\omega$ Pseudomonas. Acta path. microbiol. scand., 36, 531-536.

Lautrop, H. (1961). Aeromonas hydrophila isolated from human faeces and its possible pathological significance. Acta path. microbiol. scand., Suppl., 144, 299-301.

Lopez, J. F., Quesada, J., and Saied, A. (1968). Bacteremia and \& osteomyelitis due to Aeromonas hydrophila: a complication during the treatment of acute leukemia. Amer. J. clin. Path., 50, 587-591. 
Meeks, M. V. (1963). The genus Aeromonas: methods for identification. Amer. J. med. Technol., 29, 361-378.

Miles, A. A., and Halnan, E. T. (1937). A new species of microorganism (Proteus melanovogenes) causing black rot in eggs. $J$. Hyg. (Lond.), 37, 79-97.

Mohiedin, M. S., Gabr, S., El-Hefny, A., Mahmoud, S. S., and Abdallah, A. (1965). Bacteriological and clinical studies in infantile diarrhoea. Pt. I. Known pathogens: shigella, salmonella and enteropathogenic E. coli. J. trop. Pediat, 11, 69-78.

Pauxková, V., and Fukalová, A. (1968). Occurrence of Aeromonas hydrophila and Aeromonas shigelloides in feces. Zbl. Bakt. I. Abt. Orig., 206, 212-216.

Pittman, M. (1953). A study of bacteria implicated in transfusion reactions and of bacteria isolated from blood products. J. Lab. clin. Med., 42, 273-288.

Rosner, R. (1964). Aeromonas hydrophila as the etiologic agent in a case of severe gastroenteritis. Amer. J. clin. Path., 42, 402-404.

Sanarelli, G. (1891). Ueber einen neuen Mikroorganismus des Wassers, welcher fur Thiere mit veraenderlicher und konstanter
Temperatur Pathogen ist. Zbl. Bakt., 9, 193-199.

Schubert, R. H. W. (1967). The taxonomy and nomenclature of the genus Aeromonas. Khuyver and van Niel, 1936. Part I. Suggestion on the taxonomy and nomenclature of the aerogenic Aeromonas species. Int. J. Syst. Bact., 17, 23-37.

Slotnick, I. J. (1970). Aeromonas species isolates. Ann. N.Y. Acad. Sci., 174, 503-510.

Sonnenwirth, A. (1970). Bacteremia with and without meningitis due to Yersinia enterocolitica, Edwardsiella tarda, Comamonas terrigena and Pseudomonas maltophilia. Ann. N.Y. Acad. Sci. 174, 488-502.

von Graevenitz, A., and Mensch, A. H. (1968). The genus Aeromonas in human bacteriology. New Engl. J. Med., 278, 245-249.

von Graevenitz, A., and Zinterhofer, L. (1970). The detection of Aeromonas hydrophila in stool specimens. Hlth Lab. Sci., 7, $124-127$.

Wilson, G. S., and Miles, A. A. (1964). In Topley and Wilson's Principles of Bacteriology and Immunology, 5th ed., vol. 1, pp. 644-645. Williams and Wilkins, Baltimore.

\section{Reports and Bulletins prepared by the Association of Clinical Biochemists}

The following reports and bulletins are published by the Association of Clinical Biochemists. They may be obtained from The Administrative Office, Association of Clinical Biochemists, 7 Warwick Court, Holborn, London, WC1R 5DP. The prices include postage, but air mail will be charged extra. Overseas readers should remit by British Postal or Money Order. If this is not possible the equivalent of $50 \mathrm{p}$ is the minimum amount that can be accepted.

\section{SCIENTIFIC REPORTS}

3 Automatic Dispensing Pipettes. An assessment of 35 commercial instruments 1967 P. M. G. BROUGHTON, A. H. GOWENLOCK, G. M. WIDDOWSON, and K. A. AHLQUIST $80 \mathrm{p}(\$ 2)$

4 An Evaluation of five Commercial Flame Photometers suitable for the Simultaneous Determination of Sodium and Potassium March 1970 P. M. G. BROUGHTON and J. B. DAWSON $80 \mathrm{p}(\$ 2)$

\section{SCIENTIFIC REVIEWS}

1 The Assessment of Thyroid Function March 1971 F. V. FLYNN and J. R. HOBBS $60 \mathrm{p}(\$ 1.50)$

2 Renal Function Tests Suitable for Clinical Practice January 1972 F. L. MITCHELL, N. VEALL, and R. W. E. WATTS $60 \mathrm{p}(\$ 1.50)$

\section{TECHNICAL BULLETINS}

9 Determination of Urea by AutoAnalyzer November 1966 RUTH M. HASLAM 40p (\$1)

11 Determination of Serum Albumin by AutoAnalyzer using Bromocresol Green October 1967 B. E. NORTHAM and G. M. WIDDOWsON 40p (\$1)

13 An Assessment of the Technicon Type II Sampler Unit March 1968 B. C. GRAY and G. K. MCGOWAN 40p (\$1)

14 Atomic Absorption Spectroscopy. An outline of its principles and a guide to the selection of instruments May 1968 J. B. DAWSON and P. M. G. BROUGHTON $40 \mathrm{p}(\$ 1)$
15 A Guide to Automatic Pipettes (2nd edition) June 1968 P. M. G. BROUGHTON 40p (\$1)

16 A Guide to Automation in Clinical Chemistry May 1969 P. M. G. BROUGHTON 60p (\$1.50)

17 Flame Photometers (2nd edition) 1969 P. WILDING $60 \mathrm{p}(\$ 1.50)$

18 Control Solutions for Clinical Biochemistry (4th edition) March 1970 P. M. G. BROUGHTON 60p $(\$ 1.50)$

19 Spectrophotometers. A comparative list of low-priced instruments readily available in Britain May 1970 C. E. WILDE and P. SEWELL $60 \mathrm{p}(\$ 1.50)$

20 Quantities and Units in Clinical Biochemistry June 1970 P. M. G. BROUGHTON 60p (\$1.50) More than 30 copies in units of 10 at $20 \mathrm{p}$

21 Filter Fluorimeters: A comparative list of 18 instruments September 1970 H. BRAUNSBERG and S. S. BROWN $60 \mathrm{p}(\$ 1.50)$

22 Bilirubin standards and the Determination of Bilirubin by Manual and Technicon AutoAnalyzer Methods January 1971 BARBARA BILLING, RUTH HASLAM, and N. WALD $60 \mathrm{p}(\$ 1.50)$

23 Interchangeable Cells for Spectrophotometers and Fluorimeters September 1971 E. S. BROWN and A. H. GOWENLOCK 60p ( $\$ 1.50)$

24 Simple Tests to Detect Poisons March 1972 B. W. MEADE et al. $\quad 60 \mathrm{p}(\$ 1.50)$

25 Blood Gas Analysers May 1972 K. DIXoN 60p (\$1.50) 